\title{
Hospitalização: o impacto na criança, no adolescente e no psicólogo hospitalar
}

\author{
Sandra Padilha ${ }^{1}$
}

Nigro, M. (2004). Hospitalização: o impacto na criança, no adolescente e no psicólogo hospitalar. São Paulo: Casa do Psicólogo, 123 p.

Como compreender o choque da doença e da internação em crianças e adolescentes? Qual é o sentimento do psicólogo hospitalar ao atender pacientes internados num hospital geral? Essas perguntas encontram respostas no decorrer da leitura do livro escrito pela psicóloga Magdalena Nigro, professora da Unisa/SP e da Fundação Escola de Sociologia e Política de São Paulo.

Compõe-se a obra do prefácio, introdução, quatro capítulos e considerações finais que retratam a inquietante busca da autora por uma prática psicanalítica que superasse os limites daquela que vinha exercendo. No capítulo I, O método, a autora inicialmente descreveu as atuações desenvolvidas pelos psicólogos no hospital. Esse trabalho inclui o uso de psicoterapia breve focalizada nas emoções dos pacientes geradas pela doença e pela internação, técnica essa baseada na teoria psicanalítica. A metodologia da pesquisa que subsidiou a elaboração do capítulo foi o estudo de seis casos no hospital, sendo o levantamento dos dados efetuado mediante entrevistas semidirigidas e a aplicação da técnica do Desenho da Figura Humana com história. O número de sessões realizadas com os pacientes variou entre uma e cinco e dependeu do tempo de internação do sujeito. Para responder à segunda indagação do estudo em questão, ou seja, a experiência do psicólogo hospitalar ao atender o paciente internado, foram convidados 36 alunos do curso de Psicologia Hospitalar, dos quais 35 responderam espontaneamente e por escrito.

No capítulo II, O contexto teórico da pesquisa: um olhar psicanalítico, a autora se apropria de alguns conceitos psicanalíticos referentes à função terapêutica para iluminar a compreensão da prática do trabalho hospitalar. Sugere a apropriação dessa teoria com o objetivo de orientar o olhar ao comportamento não observável, ou seja, do latente da fala desses sujeitos no âmbito hospitalar. A compreensão acerca das experiências e vivências dos psicólogos hospitalares é apoiada nos escritos de Freud, Mezan, Cesarotto, Fuks, Lacan, entre outros. Nesse sentido, o sujeito doente torna-se o depositário das fantasias recalcadas e assustadoras desses profissionais, que até pouco tempo atrás permaneciam escondidas, mas que com a mobilização das defesas projetaram-se no paciente, para em seguida voltar como conteúdos alheios - configurando uma realidade inquietante. Ao final do capítulo, a autora trabalha a relação possível entre as perdas e adoecimento, bem como o Desenho da Figura Humana como forma de investigação dos sentidos do adoecer, ambos sustentados pelo referencial psicanalítico.

A criança internada, a dor e a perda na hospitalização infantil é o título do capítulo III. Nele, a autora discute teoricamente seis casos clínicos referentes ao impacto da doença e da internação na criança. Enfatiza que o medo do desconhecido está sempre presente durante a hospitalização; as fantasias e imagens que as crianças elaboram a respeito do hospital são fundamentalmente persecutórias, pois elas remetem a situações de abandono, perda e solidão, podendo transformar-se em experiências traumáticas e no agravamento do seu estado clínico. Dessa forma, o atendimento psicológico, por meio de elementos de mediação da fala, possibilita conhecer e compreender o mundo interno da criança e do adolescente auxiliando na busca da ressignificação da doença e até mesmo da hospitalização.

A obra é finalizada com o capítulo IV, que tem o título Psicólogo hospitalar e a doença do outro. A autora relata e discute, à luz da teoria freudiana, os depoimentos dos profissionais que atuam no ambiente hospitalar. Considera que o significado do impacto sobre o psicólogo, dentre outros, está ligado ao medo do próprio adoecimento, uma triste possibilidade futura. Esse sentimento resulta na resistência em atender determinados pacientes ou na vontade de sair do hospital. Embora essa limitação possa se fazer presente, dada a condição humana, a autora conclui que o psicólogo hospitalar pode oferecer ao paciente uma escuta diferenciada dos demais profissionais da saúde, permitindo que ele possa pensar nas emoções envolvidas no seu adoecimento e na possibilidade de colaborar com sua recuperação. Em síntese, a autora busca por meio desse estudo explicitar que o psicanalista, no hospital, pode colaborar com a humanização do atendimento ao paciente internado e de sua família, minimizando o impacto da despersonalização decorrente do adoecimento.

Cabe ressaltar, no que se refere à metodologia da pesquisa, que seria interessante a elucidação do método empregado para a análise das entrevistas, explicitando as regras e os princípios de análise, com vistas a

\footnotetext{
${ }^{1}$ Endereço para correspondência:

E-mail: sandrap@unochapeco.rct-sc.br
} 
permitir mais força e valor à pesquisa. Não obstante, recomenda-se esta obra não apenas aos profissionais que atuam diretamente no âmbito hospitalar, mas também a estudantes e profissionais de Psicologia que queiram refletir sobre as estratégias para minimizar o sofrimento dos pacientes, causado pelas doenças e hospitalização.

Sobre a autora:

Sandra Padilha é psicóloga, especialista em Gestão de Recursos Humanos, mestranda em Psicologia pela Universidade São Francisco e professora da Universidade Comunitária Regional de Chapecó/SC. 